Teknomekanik

Vol.1, No.1, June 2018, pp. 24 31

E-ISSN: 2621 - $8720 \quad$ P-ISSN: 2621 - 9980

\title{
Effect of Strong Welding Flow on the Violence of Low Carbon Steel Results of SMAW Welding with Electrodes 7018
}

\author{
Jasman, Irzal and Pebrian \\ Jurusan Teknik Mesin, Fakultas Teknik, Universitas Negeri Padang, Indonesia
}

\begin{tabular}{l} 
Article Info \\
\hline Article history: \\
Received Jan $21^{\text {th }}, 2018$ \\
Revised April $1^{\text {th }}, 2018$ \\
Accepted May $13^{\text {th }}, 2018$ \\
\hline
\end{tabular}

Keywords:

Strong current

Low carbon steel

Welding

Electrodes

Hardness test

\section{Corresponding Author:}

Pebrian

Jurusan Teknik Mesin, Fakultas Teknik, Universitas Negeri Padang

Jln. Prof. Dr. Hamka Air Tawar, Padang (25131), Sumatera Barat, Indonesia

Email: febrianian999@yahoo.co.id

\section{INTRODUCTION}

Welding is an inseparable part of growth in the industrial sector because it plays an important role in the engineering and repair of metal production. It is almost impossible to construct a factory without involving the welding process. Based on the definition of the Deutche Industrie Normen (DIN), "Welding is a metallurgical bond on metal joints or combination that carried out in melting or liquid conditions" [1]. Welding is an activity of connecting two parts of objects or more by heating, pressing or a combination of the two in such a way that it blends like a whole object. Connecting can be with or without the same amount material (metal filler) or different points of melting or structures [2]. Welding is a way to correlate the solid objects which is melting the object by heating. In simple ways, it can be interpreted that welding is the process of joining two metals using either amount material or not, and using heat energy to melt the welded material and welding wire as the filler metal. Welding can be interpreted by the process of joining two metals to melt the welding point, with or without the use of amount material and use heat energy to melt the welded material.

One of the welding that is often used in the welding filed is the SMAW (shielded metal arc welding) process or the wrapped electrode electric arc. The base metal undergoes the melting due to heating from an electric arc arising between the tip of the electrode and the surface of the work piece and then freezes together. The electrode used is a wire wrapped in a protective flux. Inside the flux wrapped electrode welding has an important role, such as: arc stabilizer and cause of smooth transfer of metal liquid grains, source of slag or gas that will protect the molten metal from outside air influences. SMAW welding is a protected electric arc welding where heat is generated from the electric arc between the tip of the electrode and the metal being welded [3]. Ferrous metal is the most widely used metals in the fabrication field, many people used this metal because the strength possessed in addition to it is very easy in the processing process, relative prices and also availability are quite easy to obtain, so there is quite a lot of people use this ferrous metal for fabrication requirements. Low carbon steel is a type of steel that is relatively cheap and easy to obtaincompared to other metals that are relatively expensive and difficult to obtain in the market [4]. 
States that carbon steel is a mixture of iron and carbon with few $\mathrm{Si}, \mathrm{Mn}, \mathrm{P}, \mathrm{S}$ and $\mathrm{Cu}$. Low carbon steel is a metal material that is easily processed by welding techniques because it contains quite high iron content. The welding process can change the properties of the metal. For example, when the condition is melting, and the reactive material to the surrounding material such as airborne gases such as oxygen, hydrogen, water vapor and so on. The reaction results will blend with the welding results. When the heating process objects expand and when cooling the steel shrinks. The balance of expansion and shrinkage speed will affect the nature of the metal and leave the load in the metal. Metal can be damaged if the load exceeds the loadbearing capability. This is very closely related to the strength of the electric current, toughness, welding defects, and cracks which generally have a fatal effect on the safety of the welded metal construction [5].

He states that the nature of sagat steel is influenced by carbon content, which actually affects the nature of steel rather than its own carbon content, but the microstructure, steel with the same chemical composition can have very different properties if the microstructure is different [6]. Materials and processes are affected the quality of workmanship due to changes in metallurgy, deformation and thermal stress is closely related to toughness, defects, cracks and corrosion. This will affect physically and mechanically the weld construction. The physical properties of metals can be interpreted as the metal's ability to accept changes in temperature, electricity and magnetic properties, while mechanical properties can be interpreted as reactions or the ability of a metal material to withstand loads, both static and dynamic [7].

Metals do not all have good weldability. Materials that have good weldability are low carbon steel. This steel can be welded by wrapping electrode arc welding, soak arc welding, and MIG welding (precious metal welding). Low alloy steel is usually used for thin plates and general construction. Welding with SMAW uses welding wire (electrode) which consists of one core made of metal coated with a layer of chemical mixture. The function of the electrode is as a generator and as added material. The electrode consists of two parts, the webbed part (flux) and un-webbed which is the tip for clamping the welding pliers. The function of flux is to protect the molten metal from the influence of outside air, produce a protective gas, and stabilize the arc.

The flux material that used for E7018 type electrodes is low iron and hydrogen powder. This type produces low hydrogen connections so that the sensitivity of the cracks is very low and the toughness is good. E-7018 electrode is a type of electrode that has certain specifications. In this study what is meant by E7018 are: [8].

E : Electric welding electrodes (E7018 diameter $3.2 \mathrm{~mm}$ ).

70 : Minimum tensile stress from welding results (70,000psi) or equal to $492 \mathrm{Mpa}$.

1 : Welding position (can be used at all welding position).

8 : Type of hydrogen iron powder film is low and the welding current interval is suitable for welding.

Strong setting of the welding current will affect the weld. If the current that used is too low, it will cause the difficulty of igniting the electric arc, the electric arc that occurs is not stable. The heat that occurs is not enough to melt the electrode and the base material so that the result is small and uneven welding teeth and a deep penetration. Conversely, if the welding current is too high, the electrode will melt too fast and will produce a wide weld surface and deep penetration so as to produce low tensile strength and increase fragility of the welding results [9]. The strength of weld results is affected by arc stress, magnitude of current, welding speed. Determination of the amount of current in metal connection with arc welding affects the work efficiency and welding material. The results of the observations from the problem above, the writer identify the existing problems as follows:

1. The difference in strong welding currents can affect the hardness of low carbon steel.

2. Strong setting of the welding current will affect the weld.

3. The welding process can be changed the properties of metals.

In order to make it more focus, the author limits the problem to the effect of welding current on the hardness of low carbon steel welded by SMAW with a 7018 electrode and diameter of $3.2 \mathrm{~mm}$. The formulation of the problem as follows: "Does the welding current strength affect the hardness of the low carbon steel from the welding results of SMAW". The main purpose of this study is: To find out whether welding current will be affected on the low carbon steel hardness of SMAW welding results with E7018 electrode.

\section{METHOD}

\subsection{Types of Research}

This research is an experimental research, the data is obtained from the results of research through testing about the hardness of metal in the laboratory. "Experimental research methods can be interpreted as 
research methods that used to find out the influence of treatment on others under controlled conditions". This study aims to determine the hardness of low carbon steel from SMAW welding using 7018 electrodes and different welding currents. [10].

\subsection{Time and Place}

The time of this research was conducted on April-July 2018. Start from the submission of proposals, making specimens, testing, and making the research report. This research was conducted at the mechanical engineering workshop and laboratory testing materials for mechanical engineering majoring in the Faculty of Engineering, Universitas Negeri Padang

\subsection{Research Objects}

The specimens that used in this study were low carbon steel plate ST 37 size $56 \mathrm{~mm}$ x $10 \mathrm{~mm}$ x $10 \mathrm{~mm}$ with the total number of specimens, namely 12 specimens, of which 3 were Raw Material specimens, 3 specimens with a welding of 100A current, 3 specimens with welding 130A current strength, 3 specimens with 160A current welding, $3.2 \mathrm{~mm}$ diameter E7018 electrode. The welding position that is performed is the down hand welding position. The welding-joint that used was Campuh V with a $60^{\circ}$ included angle. The results of the SMAW welding were then tested for hardness with a universal hardness tester (universal hardness tester).

\subsection{Types and Sources of Data}

2.4.1 Types of Data

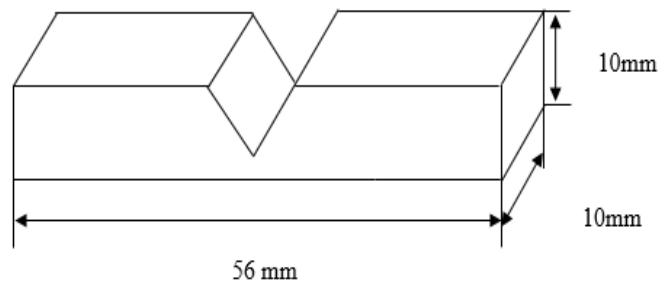

Figure 1 : Research Specimen

The type of data used is primary data that obtained from the results of the test in the form of metal hardness test that has been welded with SMAW welding using 7018 electrodes and different welding currents.

\subsubsection{Sources of Data}

Sources of data from this study are the results of metal hardness testing, from specimens that have been welded with SMAW welding with E7018 electrodes. This test was carried out in a laboratory Testing Material for Mechanical Engineering Department FT-UNP.

\subsection{Tools and Materials}

\section{Tools}

The tools that used are:
a. Hardness Testing Machine (Universal Hardness Tester)
b. Milling machine and its equipment
c. SMAW welding machine and its equipment
d. Pliers
e. Slag Hammer
f. Hacksaw
g. Steel brush
h. Miser
i. Sandpaper
j. Calipers
k. Bevel protector 


\section{Materials}

The materials that used are:

The material used in this study is low carbon steel ST 37 with the size of $56 \mathrm{~mm} \times 10 \mathrm{~mm} \times 10 \mathrm{~mm}$. Then the metal welding was done by testing the material with welding SMAW using E7018 with diameter $3.2 \mathrm{~mm}$. The electrode using different currents; they are 100A for 3 research specimens, 130A for 3 research specimens, and 160A for 3 research specimens.

\subsection{Research Process}

\section{Preparation}

The material used in this study was low carbon steel with a length of $80 \mathrm{~mm}$, width of $80 \mathrm{~mm}$, and thickness of $10 \mathrm{~mm}$ as many as 4 specimens. The electrode used is an E7018 type electrode with a diameter of $3.2 \mathrm{~mm}$.

2. Preparation of Tools
a. SMAW welding machine
b. Hardness Testing Machine (Universal Hardness Tester)
c. Pliers
d. Welding hammer
e. Hacksaw
f. Steel brush
g. Miser
h. Sandpaper
i. Calipers
j. Bevel protector

3. Process of Specimens Distribution

Distribution of test specimens is carried out with the following details:

a. Specimen A was 3 specimens, namely Raw Material specimen and hardness test.

b. Specimen B is 3 specimens, which are specimens that are welded with a current of $100 \mathrm{~A}$ and carried out in hardness.

c. Specimens $C$ were 3 specimens, namely specimens welded with $130 \mathrm{~A}$ current and tested for hardness.

d. Specimens D were 3 specimens, namely specimens welded with 160 A currents and tested for hardness

\section{Making Campuh V}

Campuh $\mathrm{V}$ is used for joining metal or plate with thickness of $6-20 \mathrm{~mm}$ with angle of seam between $50^{\circ}$ - 70 ${ }^{\circ}$, root distance 0-2 $\mathrm{mm}$, root height 0-3 $\mathrm{mm}$. Making campuh $\mathrm{V}$ boot is using a milling machine. Prepare the material, then measured it with $2 \mathrm{~mm}$ deep and drawn at an angle of $30^{\circ}$ at the end of the test object. After the test material has been drawn, do the mill with $30^{\circ}$ angle that has been made which was previously drawn using a milling machine. [ 11 ].

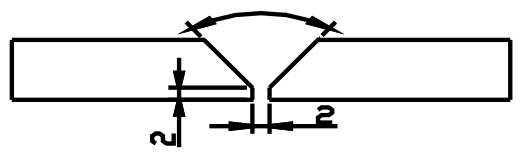

Figure 2 : Campuh V

\section{Welding Process}

In this research, specimen welding is carried out by a certified welder to achieve the welding results. The welding steps are as follows:

a. Prepare SMAW welding machines and equipment.

b. Prepare the work piece to be welded on the root face. The camp used was type $\mathrm{V}$ with an included angle of $60^{\circ}$ with a root gap $2 \mathrm{~mm}$. 
c. Prepare electrodes. In this study the electrode used was type E7018.

d. Welding position using the welding position horizontally or under the hand.

e. Do welding on the object to be tested, in this study there were 3 specimens to be welded with the variety strength of welding current, which are specimen B with a welding current strength of $100 \mathrm{~A}$, specimen C with a current of $130 \mathrm{~A}$ and D specimen with a current strength of $160 \mathrm{~A}$.

\section{Making Specimens}

After the welding process is finished, make sure the specimens that to be tested are cleaned first by the welding groove using a milling machine, and then cut to size, $56 \mathrm{~mm}$ long, $10 \mathrm{~mm}$ wide, and $10 \mathrm{~mm}$ thick.

7. Process of Hardness Testing

The initial test of the specimen using the following steps:

a. Prepare the test of specimens by sanding the surface.

b. Before testing the specimen, the specimen is inserted into the exaqueous liquid to find out the test point taking areas.

c. Select the indentor to be used $(2.5 \mathrm{~mm})$.

d. Installing an indent ball on the universal hardness tester test machine.

e. Install ballast on the test machine $(1840 \mathrm{~N} / 178.5 \mathrm{~kg})$.

f. Put the test of specimen on the root face.

g. Set the root face until it touches the indenter ball.

h. Calibrating the universial hardness tester machine measuring instrument at zero position.

i. Pressing the indenter ball on the test specimen with a load of $1840 \mathrm{~N}$.

j. Press the indenter ball for about 10 seconds.

k. Returns the indenter ball position in the starting position by pulling back the load given.

1. Record the amount of hardness listed on the universial hardness tester.

$\mathrm{m}$. Change the position of the test point and continue testing the hardness by applying the steps as above.

\subsection{Instrument of Data Collection}

The technique of data collection in this study is through testing with the following testing aspects:

a. Cleansing the specimen by sanding the surface until smooth according to the roughness level of the sandpaper.

b. Smooth the surface of the specimen with a cloth and use toothpaste / toothpaste that contain alumina to smooth the surface of the specimen to be tested.

c. Wash the specimen with pure water and use the soap to remove the rust that is stuck on the surface of the specimen.

d. Dry all specimens with a fan.

e. Insert the specimen into a container that contains the alcohol to remove any dirt or rust on the specimen surface.

f. Pour etching liquid into a container which is made of plastic or glass, then put the specimen into etching liquid to find out the parent metal regions, and the HAZ area, and also the weld area. Etching is classified as hydrochloric acid found naturally in the intestine as an ingredient in human digestive fluids. If it spills on the skin, this acid will actually damage to human flesh. In the industrial world, hydrochloric acid is used in skin processing and to remove iron-oxide and rust from steel. Drugs users choose it to ingest these corrosive acids into their bodies.

g. Give a sign to the parent metal areas, HAZ area and weld area for the testing process of each point taking.

After each test point is taken, do observations and measurements with a microscope at each inductor / former pressure point and the results can be entered in the table with column symbol $=\mathrm{d}$.

\subsection{Technique of Data Analysis}

The method of data analysis is done by mathematical data analysis that applies in several equations. Mathematical calculations can be obtained from low carbon steel test specimens.

1. Based on the results of the Brinel hardness calculation with the formula:

Journal homepage: http://teknomekanik.ppj.unp.ac.id

DOI: https://doi.org/10.24036/tm.v1i1.972 


$$
B H N=\frac{2 P}{\left.\pi D D-\sqrt{D^{2}}-d^{2}\right)}
$$

2. Based on the Brinell test by converting into a table.

In order to find the value of hardness test results, it is commonly seen based on the conversion table; the value indicated on the indentor dial of the test machine is converted into the conversion table. For example, the result is indication on gauge 40; the conversion result is $158 \mathrm{BHN}$. After the specimen test results are obtained, it is necessary to do an analysis of the mean and percentage of the average hardness values on the low carbon steel specimens in the parent metal area, and the HAZ area, also the weld area.

\section{RESULTS AND DISCUSSION}

In this section, it is explained the results of research and at the same time is given the comprehensive discussion. Results can be presented in figures, graphs, tables and others that make the reader understand easily [2], [5].

The method in processing of data is carried out by mathematical data analysis which applies in several equations. Mathematical calculations can be obtained from a variety of low carbon steel ST 37 welded SMAW test specimens with different current strengths using an E-7018 electrode.

Table 1. Results of Observation of Brinell Method Hardness Testing on Low Carbon Steel Welding Results with a Current Strength of 100 A Using E7018 Electrodes.

\begin{tabular}{|l|c|c|c|c|c|c|}
\hline \multirow{3}{*}{ No } & \multicolumn{2}{|c|}{ Logam induk } & \multicolumn{2}{c|}{ Daerah HAZ } & \multicolumn{2}{c|}{ Daerah Las } \\
\cline { 2 - 7 } & Praktek & Teori & Praktek & Teori & Praktek & Teori \\
\cline { 2 - 7 } & $\mathbf{H B}$ & $\mathbf{H B}$ & $\mathbf{H B}$ & $\mathbf{H B}$ & $\mathbf{H B}$ & $\mathbf{H B}$ \\
& $\mathbf{K g f}$ & $\mathbf{K g f}$ & $\mathbf{\text { Kgf }}$ & $\mathbf{\text { Kgf }}$ & $\begin{array}{c}\text { Kgf } \\
\text { Kgf }\end{array}$ \\
\hline 1 & 143 & 187,35 & 155 & 155,60 & 153 & 187,35 \\
\hline 2 & 147 & 187,35 & 155 & 187,35 & 153 & 187,35 \\
\hline 3 & 149 & 155,60 & 151 & 187,35 & 149 & 187,35 \\
\hline 4 & 149 & 155,60 & 151 & 155,60 & 151 & 155,60 \\
\hline 5 & 147 & 155,60 & 149 & 187,35 & 153 & 155,60 \\
\hline 6 & 145 & 187,35 & 153 & 187,35 & 149 & 187,35 \\
\hline 7 & 151 & 187,35 & 147 & 187,35 & 151 & 187,35 \\
\hline 8 & 147 & 155,60 & 147 & 187,35 & 151 & 155,60 \\
\hline 9 & 147 & 187,35 & 149 & 187,35 & 149 & 187,35 \\
\hline $\begin{array}{c}\text { Rata- } \\
\text { rata }\end{array}$ & 147,2222 & 173,2389 & 150,7777 & 173,2389 & 151 & 176,7666 \\
\hline
\end{tabular}

Table 2. Results of Observation of Brinell Method Hardness Testing on Low Carbon Steel Welding Results with a Strength of 130 A Flow Using E-7018 Electrodes.

\begin{tabular}{|l|c|c|c|c|c|c|}
\hline \multirow{3}{*}{ No } & \multicolumn{2}{|c|}{ Logam induk } & \multicolumn{2}{c|}{ Daerah HAZ } & \multicolumn{2}{c|}{ Daerah Las } \\
\cline { 2 - 7 } & Praktek & Teori & Praktek & Teori & Praktek & Teori \\
\cline { 2 - 7 } & $\mathbf{H B}$ & $\mathbf{H B}$ & $\mathbf{H B}$ & $\mathbf{H B}$ & $\mathbf{H B}$ & HB \\
& Kgf & Kgf & Kgf & Kgf & $\begin{array}{c}\text { Kgf } \\
\text { Kgf }\end{array}$ \\
\hline 1 & 147 & 187,35 & 147 & 187,35 & 158 & 187,35 \\
\hline 2 & 147 & 187,35 & 151 & 187,35 & 161 & 187,35 \\
\hline 3 & 143 & 155,60 & 149 & 187,35 & 158 & 187,35 \\
\hline 4 & 151 & 187,35 & 158 & 155,60 & 147 & 187,35 \\
\hline 5 & 147 & 155,60 & 155 & 187,35 & 149 & 187,35 \\
\hline 6 & 149 & 187,35 & 149 & 187,35 & 151 & 187,35 \\
\hline 7 & 149 & 187,35 & 149 & 187,35 & 161 & 187,35 \\
\hline 8 & 153 & 187,35 & 151 & 187,35 & 164 & 187,35 \\
\hline 9 & 151 & 187,35 & 153 & 187,35 & 164 & 187,35 \\
\hline $\begin{array}{c}\text { Rata- } \\
\text { rata }\end{array}$ & 148,5555 & 180,2944 & 151,3333 & 183,8222 & 157 & 187,5 \\
\hline
\end{tabular}

Table 1 show that the mean value of the hardness test practically on the low carbon steel specimens welded by SMAW with a current strength of 100A using the E-7018 electrode the highest value is $176.7666 \mathrm{~kg} / \mathrm{mm}^{2}$ in theoretical weld metal area. Meanwhile, the mean value of the hardness test practically on the low carbon steel specimens welded by SMAW with 130A current strength using E-7018 electrode the highest value is $187.5 \mathrm{~kg} / \mathrm{mm}^{2}$ in theoretical weld metal area (Table 2). 
Table 3. Results of Observation of Brinell Method Hardness Testing on Low Carbon Steel Welding Results with Current Strength of 160 A Using E7018 Electrode.

\begin{tabular}{|l|c|c|c|c|c|c|}
\hline \multirow{3}{*}{ No } & \multicolumn{2}{|c|}{ Logam induk } & \multicolumn{2}{c|}{ Daerah HAZ } & \multicolumn{2}{c|}{ Daerah Las } \\
\cline { 2 - 7 } & Praktek & Teori & Praktek & Teori & Praktek & Teori \\
\cline { 2 - 7 } & $\begin{array}{c}\text { HB } \\
\text { Kgf }\end{array}$ & $\begin{array}{c}\text { HB } \\
\text { Kgf }\end{array}$ & $\begin{array}{c}\text { HB } \\
\text { Kgf }\end{array}$ & $\begin{array}{c}\text { HB } \\
\text { Kgf }\end{array}$ & $\begin{array}{c}\text { HB } \\
\text { Kgf }\end{array}$ & $\begin{array}{c}\text { HB } \\
\text { Kgf }\end{array}$ \\
\hline 1 & 147 & 187,35 & 147 & 155,60 & 151 & 155,60 \\
\hline 2 & 147 & 187,35 & 151 & 155,60 & 147 & 155,60 \\
\hline 3 & 151 & 155,60 & 149 & 187,35 & 153 & 187,35 \\
\hline 4 & 149 & 155,60 & 151 & 187,35 & 151 & 187,35 \\
\hline 5 & 151 & 187,35 & 149 & 187,35 & 153 & 187,35 \\
\hline 6 & 149 & 187,35 & 147 & 155,60 & 149 & 187,35 \\
\hline 7 & 145 & 155,60 & 149 & 187,35 & 147 & 187,35 \\
\hline 8 & 151 & 187,35 & 149 & 187,35 & 147 & 187,35 \\
\hline 9 & 147 & 187,35 & 149 & 187,35 & 149 & 187,35 \\
\hline $\begin{array}{c}\text { Rata- } \\
\text { rata }\end{array}$ & 148,5555 & 176,7666 & 149 & 176,7666 & 149,6666 & 180,2944 \\
\hline
\end{tabular}

Table 4. Results of Observations of Brinell Method Hardness Testing by Using Raw Material.

\begin{tabular}{|l|c|c|c|c|c|c|}
\hline \multirow{4}{*}{ No } & \multicolumn{2}{|c|}{ Raw Mateial 1 } & \multicolumn{2}{c|}{ Raw Mateial 2 } & \multicolumn{2}{c|}{ Raw Mateial 3 } \\
\cline { 2 - 7 } & Praktek & Teori & Praktek & Teori & Praktek & Teori \\
\cline { 2 - 7 } & $\mathbf{H B}$ & $\mathbf{H B}$ & $\mathbf{H B}$ & $\mathbf{H B}$ & $\mathbf{H B}$ & $\mathbf{H B}$ \\
& $\mathbf{K g f}$ & $\mathbf{K g f}$ & $\mathbf{K g f}$ & $\mathbf{K g f}$ & $\mathbf{K g f}$ & $\mathbf{K g f}$ \\
\hline 1 & 151 & 187,35 & 153 & 155,60 & 153 & 155,60 \\
\hline 2 & 153 & 187,35 & 155 & 187,35 & 153 & 155,60 \\
\hline 3 & 153 & 155,60 & 151 & 155,60 & 151 & 187,35 \\
\hline 4 & 155 & 155,60 & 155 & 155,60 & 151 & 155,60 \\
\hline 5 & 153 & 155,60 & 153 & 155,60 & 155 & 155,60 \\
\hline 6 & 155 & 155,60 & 151 & 187,35 & 155 & 155,60 \\
\hline 7 & 153 & 187,35 & 153 & 155,60 & 151 & 187,35 \\
\hline 8 & 151 & 155,60 & 151 & 187,35 & 153 & 155,60 \\
\hline 9 & 155 & 155,60 & 155 & 155,60 & 153 & 187,35 \\
\hline $\begin{array}{c}\text { Rata- } \\
\text { rata }\end{array}$ & 153,2222 & 166,1833 & 153 & 166,1833 & 152,7777 & 166,1833 \\
\hline
\end{tabular}

Table 3 show the mean value of the hardness test practically on low carbon steel specimens welded to SMAW with a current strength of 160 A using E-7018 electrode the highest value is $180.2944 \mathrm{~kg} / \mathrm{mm}^{2}$ in theoretical weld metal area. The mean value of hardness in Raw Materials is $166.18 \mathrm{~kg} / \mathrm{mm}^{2}$ in theory $152.22 \mathrm{~kg} / \mathrm{mm}^{2}$ (Table 4).

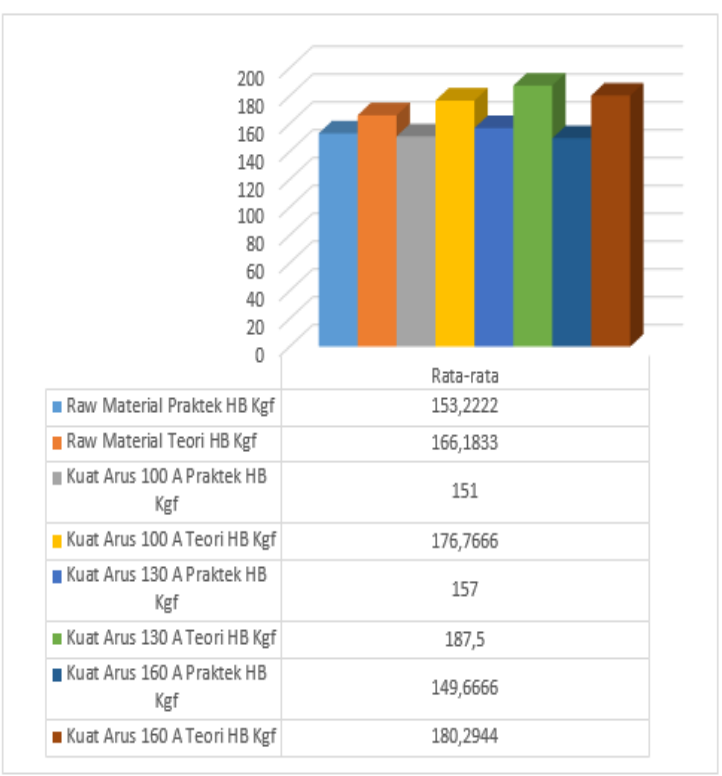

Figure 3 : Comparison Chart of Hardness Test of Low Carbon Steel Raw Material And Welding Results of SMAW with Current Strength Different Using E-7018 Electrodes.

Comparison of hardness test Low carbon steel welded SMAW with different current strength by Using E7018 electrode. The picture 3 shows the comparison of hardness test results of low carbon steel raw material and welds of SMAW with different current strength using E-7018 electrode obtained from the test specimens of raw material and which have been welded with welding current strength of 100A, 130A, and 160A. From the test the highest values obtained in the specimen with $130 \mathrm{~A}$ welding current strength is $157 \mathrm{~kg} / \mathrm{mm} 2 \mathrm{in}$ practice, and $187.5 \mathrm{~kg} / \mathrm{mm} 2$ in theory. The hardness test results show that the low carbon steel specimens welded by SMAW with different welding currents using E-7018 electrodes. In low carbon steel specimens with 130A welding current strength using E-7018 electrode, higher drought value compared to low carbon steel specimens produced by SMAW with current strength of $100 \mathrm{~A}$ and $160 \mathrm{~A}$ using E-7018 electrodes. 


\section{CONCLUSION (10 PT)}

The results of the hardness testing obtained on the low carbon steel specimens welded by SMAW with different welding current strength using E-7018 electrode, the hardness value is different.

1. The mean value of the hardness test practically on the low carbon steel specimens welded by SMAW with a current strength of $100 \mathrm{~A}$ using the E-7018 electrode the highest value is $176.7666 \mathrm{~kg} / \mathrm{mm}^{2}$ in theoretical weld metal area

2. The mean value of the hardness test practically on the low carbon steel specimens welded by SMAW with a current strength of $130 \mathrm{~A}$ using electrodes E-7018 the highest value is $187.5 \mathrm{~kg} / \mathrm{mm}^{2}$ in the weld metal area in theory.

3. The mean value of the hardness test practically on the low carbon steel specimens welded by SMAW with a current strength of $160 \mathrm{~A}$ using electrodes E-7018 the highest value is $180.2944 \mathrm{~kg} / \mathrm{mm}^{2}$ in the weld metal area in theory.

4. The highest hardness value is found in the welding strength of $130 \mathrm{~A}$ which is equal to $187.5 \mathrm{~kg} / \mathrm{mm} 2 \mathrm{in}$ theory in the weld metal area, and $157 \mathrm{~kg} / \mathrm{mm} 2$ in practice in the weld metal area. $130 \mathrm{~A}$ welding current strength is good for $3.2 \mathrm{~mm}$ electrode diameter.

5. If the welding current strength is used below the standard current strength of the electrode size and thickness of the material (100A), it will cause the difficulty of igniting the electric arc on the electrode, the heat that occurs is not enough to melt the electrode and the base material. So that the results are small hollow and uneven weld.

6. If the welding current strength used above the standard current strength of the electrode size and thickness of the material (160A), it will cause the electrode to melt too quickly and produce a wide weld surface and deep penetration resulting in low tensile strength and added fragility to the weld.

\section{REFERENCES}

[1] Wiryosumarto, H. and Okumura, T. Teknologi Pengelasan Logam. Jakarta: Pratya Pramita. 2008

[2] Alip, M. Teori dan Praktik Las. Depatemen dan Kebudayaan. 1989.

[3] Suharno. Prinsip-Prinsip Teknologi dan Metalurgi Pengelasan Logam. Edisi 1. Ed. Jawa Tengah: Lembaga Pengembangan Pendidikan (LPP) UNS dan UPT penerbitan dan percetakan UNS (UNS press). 2008.

[4] Wiryosumarto, H and Okumura, T. Teknologi Pengelasan Logam. Jakarta: Pratya Pramita. 2008.

[5] Sudira, T and Saito, S. Pengetahuan Bahan Teknik, Jakarta: Pradnya Paramita, Jakarta. 1995.

[6] Rohyana, S. Pengetahuan pengolahan bahan-bahan. Bandung: Humainora Utama Prees. 1999.

[7] Smallman. 1992. Metalurgi fisik modern. Jakarta: Gramedia. 1992.

[8] Bintoro, G.A. 1999. Dasar-dasar pekerjaan las. Jilid 1. Yogyakarta: kanisius. 1999.

[9] Arifin. Las Listrik dan Otogen. Jakarta: Ghalia Indonesia. 1997.

[10] Sugiyono. Metode Penelitian Kuantitatif Kualitatif dan R\&D. Bandung: Alfabeta. 2012.

[11] Sonawan, H and Suratman, R. Pengantar Untuk memahami Pengelasan Logam. Bandung: Alfa Beta. 2004. 